\title{
Histological variability in the limb bones of the Asiatic wild ass and its significance for life history inferences
}

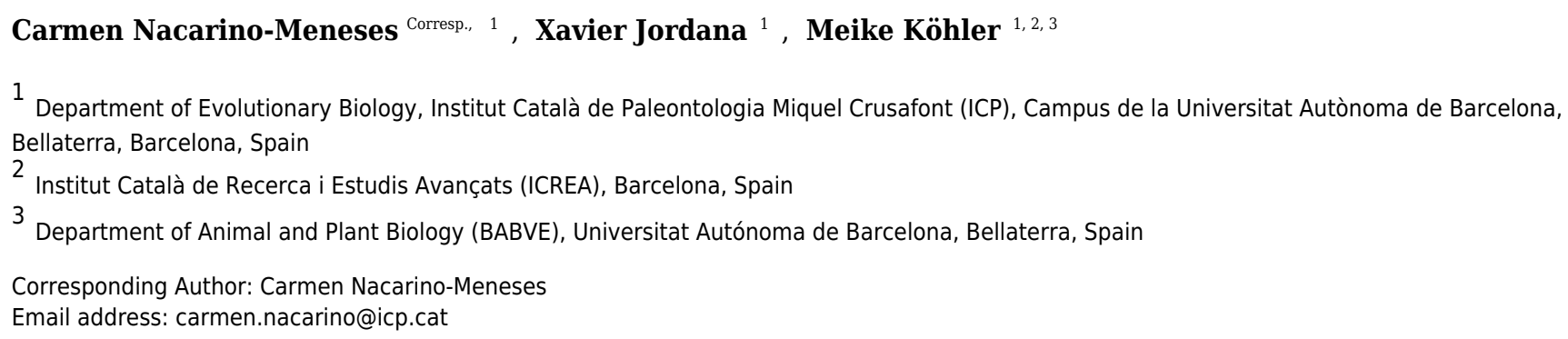

The study of the bone growth marks (BGMs) and other histological traits of the bone tissue provides insights into the life history of present and past organisms. Important life history traits like longevity or age at maturity, which could be inferred from the analysis of these features, form the basis for estimations of demographic parameters that are essential in ecological and evolutionary studies of vertebrates. Here, we study the intraskeletal histological variability in an ontogenetic series of Asiatic wild ass (Equus hemionus) in order to assess the suitability of several skeletal elements to reconstruct the life history strategy of the species. Bone tissue types, vascular canal orientation and BGMs have been analyzed in 35 cross-sections of femur, tibia and metapodial bones of 9 individuals of different sexes, ages and habitats. Our results show that the number of BGMs recorded by the different limb bones varies within the same specimen. Our study supports that the femur is the most reliable bone for skeletochronology, as already suggested. Our findings also challenge traditional beliefs with regard to the meaning of deposition of the external fundamental system (EFS). In the Asiatic wild ass, this bone tissue is deposited some time after skeletal maturity and, in the case of the femora, coinciding with the reproductive maturity of the species. The results obtained from this research are not only relevant for future studies in fossil Equus, but could also contribute to improve the conservation strategies of threatened equid species. 


\section{Article Title}

2 Histological variability in the limb bones of the Asiatic wild ass and its significance for life

3 history inferences

\section{Authors}

5 Carmen Nacarino-Meneses ${ }^{1}$, Xavier Jordana ${ }^{1}$, Meike Köhler ${ }^{1,2,3}$

\section{Affiliations}

$7 \quad{ }^{1}$ Institut Català de Paleontologia Miquel Crusafont (ICP), Campus de la Universitat Autònoma

8 de Barcelona, 08193 Bellaterra, Barcelona, Spain.

$9 \quad 2$ ICREA, Pg. Lluís Companys 23, 08010 Barcelona, Spain.

$10{ }^{3}$ BAVE department, Autonomous University of Barcelona (UAB), 08193 Bellaterra, Barcelona, 11 Spain.

\section{Corresponding author}

13 Carmen Nacarino-Meneses

14 Edifici Z (ICTA-ICP), C/ de les Columnes s/n, Bellaterra, Barcelona, 08193, Spain.

15 carmen.nacarino@icp.cat 


\section{ABSTRACT}

17 The study of the bone growth marks (BGMs) and other histological traits of the bone tissue 18 provides insights into the life history of present and past organisms. Important life history traits 19 like longevity or age at maturity, which could be inferred from the analysis of these features, 20 form the basis for estimations of demographic parameters that are essential in ecological and 21 evolutionary studies of vertebrates. Here, we study the intraskeletal histological variability in an 22 ontogenetic series of Asiatic wild ass (Equus hemionus) in order to assess the suitability of 23 several skeletal elements to reconstruct the life history strategy of the species. Bone tissue types, 24 vascular canal orientation and BGMs have been analyzed in 35 cross-sections of femur, tibia and 25 metapodial bones of 9 individuals of different sexes, ages and habitats. Our results show that the 26 number of BGMs recorded by the different limb bones varies within the same specimen. Our 27 study supports that the femur is the most reliable bone for skeletochronology, as already 28 suggested. Our findings also challenge traditional beliefs with regard to the meaning of 29 deposition of the external fundamental system (EFS). In the Asiatic wild ass, this bone tissue is deposited some time after skeletal maturity and, in the case of the femora, coinciding with the reproductive maturity of the species. The results obtained from this research are not only relevant

32 for future studies in fossil Equus, but could also contribute to improve the conservation strategies 33 of threatened equid species. 


\section{INTRODUCTION}

36 The study of bone growth marks (BGMs) is nowadays the focus of many investigations due to its

37 potential to reconstruct many aspects of the life history of present and past vertebrates (Amson et 38 al., 2015; Kolb et al., 2015a; Woodward et al., 2015; Jordana et al., 2016; Moncunill-Solé et al., 39 2016; Nacarino-Meneses, Jordana \& Köhler, 2016; Orlandi-Oliveras et al., 2016). These

40 histological features, which record cyclic variation in bone growth rate, can take the form of 41 "lines of arrested growth" (LAGs) or of "annuli" within the cortical bone (Castanet et al., 1993).

42 LAGs appear as thin dark lines in bone cross-sections and are considered to represent moments 43 of cessation of growth (Francillon-Vieillot et al., 1990; Chinsamy-Turan, 2005). Annuli, on the 44 other hand, are poorly vascularized rings of lamellar or parallel-fibered bone within the bone 45 cortex (Francillon-Vieillot et al., 1990; Chinsamy-Turan, 2005) that indicate periods of growth 46 47

48 CGMs) reflecting physiological cycles (Köhler et al., 2012) that match environmental cycles 49 50 rate decrease. From Peabody (1961) to the present, it has been repeatedly demonstrated that most of the BGMs found in the bone tissue record annual cycles of growth (cyclical growth marks (Castanet et al., 1993; Chinsamy-Turan, 2005). Nevertheless, BGMs are also suggested to register biological events that entail moments of physiological stress in the organism (Woodward, Padian \& Lee, 2013) instead of periodical growth (Castanet, 2006).

From dinosaurs to mammals, the annual periodicity of the CGMs is the basis for inferences of life history strategies in many groups of fossil organisms (e.g. Klevezal, 1996; Horner, de Riqclès \& Padian, 2000; Köhler \& Moyà-Solà, 2009). The number of CGMs within a bone cortex allows researchers to calculate important life history traits such as longevity (Castanet et al., 2004; Köhler \& Moyà-Solà, 2009; Köhler, 2010) or age at maturity (Chinsamy \& Valenzuela, 2008; Horner, de Riqclès \& Padian, 2000; Köhler \& Moyà-Solà 2009; Köhler 2010; Marín-Moratalla, Jordana \& Köhler, 2013; Jordana et al., 2016) by means of a technique called skeletochronology (Castanet et al., 1993). This method also provides information about other biological aspects of the animals such as their growth strategy or physiology (Horner, de Riqclès \& Padian, 2000; Padian, de Ricqlès \& Horner, 2001; Köhler et al., 2012; Woodward et al., 2015). However, skeletochronology has some limitations that are particularly important when

63 dealing with mammals. Firstly, the remodelling process (haversian systems) and the expansion of 64 the medullary cavity that accompany the increase in age can hide the presence of previous CGMs 
65 and, thus, give an underestimated individual age (Woodward, Padian \& Lee, 2013). The

66 inference of this important trait could also be altered if non-cyclical BGMs are erroneously

67 counted as cyclical ones. On the other hand, CGMs are difficult to identify if they are located in

68 the lamellar and avascular bone tissue deposited in the outermost cortex of adult individuals

69 (external fundamental system - EFS) (Woodward, Padian \& Lee, 2013), because of the structural

70 similarity between LAGs and the lamellae of this tissue (Horner, de Ricqlès \& Padian, 1999).

71 Such misidentification of CGMs within the EFS, along with the fact that mammals present

72 asymptotic growth (Lee et al., 2013), also reduces the accuracy of longevity estimates when old

73 specimens are analyzed (Castanet et al., 2004; Woodward, Padian \& Lee, 2013). Finally, several

74 authors had reported a variable number of CGMs depending on the bone analyzed within an

75 individual (García-Martínez et al., 2011; Woodward, Horner \& Farlow, 2014). Thus, it is

76 important to select the most appropriate bone for skeletochronological studies in each taxon

77 before making general assessments about the life history of the species (Horner, de Riqlès \&

78 Padian, 1999).

79 The histological analysis of bones for this kind of research in mammals is still little explored in

80 comparison with other vertebrate groups (Castanet et al., 2004; Kolb et al., 2015a; Jordana et al.,

81 2016). However, since the study of Köhler et al. (2012) that demonstrated the correlation

82 between cyclical bone growth and seasonal physiology in a wide sample of ruminants, the

83 number of histological works in extant (Marín-Moratalla, Jordana \& Köhler, 2013, Marín-

84 Moratalla et al., 2014; Jordana et al., 2016; Nacarino-Meneses, Jordana \& Köhler, 2016) and

85 extinct mammals (Martínez-Maza et al., 2014; Kolb et al., 2015b; Amson et al., 2015;

86 Moncunill-Solé et al., 2016; Orlandi-Oliveras et al., 2016) has considerably increased. Among

87 all mammalian clades, members of the family Equidae play a key role in extant and fossil

88 ecosystems (MacFadden, 1992; Downer, 2014). Besides, they are a classical group of research in

89 Paleontology due to their characteristic evolution (MacFadden, 2005). Nevertheless, histological

90 studies in equids are scarce and only a few aimed to infer the life history strategies of some fossil

91 (Sander \& Andrássy, 2006; Martínez-Maza et al., 2014) or extant representatives (Nacarino-

92 Meneses, Jordana \& Köhler, 2016) of the group.

93 For the reasons set out above, the main objective of the present work is to study the histological

94 variability (BGMs, pattern of vascularization, bone tissue types) between different limb bones of 
95 the same individual in the Asiatic wild ass (Equus hemionus Pallas, 1775). With this study, we

96 aim to find out what life history information can be inferred from the histological study of equids

97 and to try to determine which is the best skeletal element to develop skeletochronological studies

98 in this mammal. The kulan or Asiatic wild ass, a mammal endemic to the Gobi desert, is one of

99 the eight extant species of the family Equidae (Steiner \& Ryder, 2011) and presents nowadays a

100 delicate conservation status (Kaczensky et al., 2015). Because previous studies pointed out the

101 potential of histological analyses in conservation management of wild populations (Chinsamy \&

102 Valenzuela, 2008; García-Martínez et al., 2011; Marín-Moratalla, Jordana \& Köhler, 2013), we

103 have considered this species as the most appropriate to conduct this study. Moreover, its extant

104 habitat - the steppe and semi-desert plains of Mongolia, Iran, Turmekistan, India and China (Feh

105 et al., 2001; Reading et al., 2001; Kaczensky et al., 2015) - make this extant taxon the most

106 similar to fossil stenoid horses (Forstén, 1992) extending the importance of our research form

107 Conservation Biology to Palaeontology.

\section{2. MATERIAL AND METHODS}

109 Thin sections from femur, tibia, metatarsus and metacarpus were analyzed in an ontogenetic

110 series of 9 specimens of E. hemionus (Table 1). Only specimen IPS83154 lacks metacarpal bone,

111 totaling 35 the cross-sections studied. As shown in Table 1, the sample includes individuals from

112 different habitats, sex and ages. Sex data were provided by curators while age at death was

113 estimated according to dental eruption pattern of the species (Lkhagvasuren et al., 2013) and

114 corroborated with the analysis of cementum layers in adult individuals (R. Schafberg, pers.

115 comm.). Wild specimens (IPS83876 - IPS83877) were collected during the Mongolian-German

116 Biological Expeditions in the Gobi desert (Schöpke et al., 2012) and are housed at the Natural

117 History Collections of the Martin-Luther-University Halle-Wittenberg (Halle, Germany).

118 Captive individuals (IPS83149 - IPS83155) lived in the Hagenbeck Zoo (Hamburg, Germany)

119 and belong to the collections of the Zoological Institute of Hamburg University (Hamburg,

120 Germany).

121 From the mid-shaft of each bone, we prepared histological slices following standard procedures

122 in our laboratory (Nacarino-Meneses, Jordana \& Köhler, 2016). After measuring and

123 photographing each bone, three centimeters of its mid-shaft were cut and embedded in an epoxy 
124 resin (Araldite 2020). This block was later cut into two halves (ISO Met, Biometa) and the

125 exposed surface was polished with carborundum powder to be fixed to a frosted glass with an

126 UV curing glue (Loctite 358). Afterwards, it was cut with a diamond saw (Petrothin, Buehler) up

127 to a thickness of 100-120 microns and polished again with carborundum powder. Finally, a mix

128 of oils (Lamm, 2013) was spread over the slice before being sheltered with a cover slip.

129 Longitudinal sections were also prepared from each block, to corroborate that the identification

130 of bone tissue types do not rely on the orientation of the cutting plane (Stein \& Prondvai, 2014).

131 All thin-sections were observed in a Leica DM 2500P microscope under polarized light with a

$1321 / 4 \lambda$ filter and photographed with the camera incorporated in the microscope. The use of a

133 retardation filter that colors the cross-section, which is not mandatory in this kind of studies, was

134 used to improve the visualization of BGMs and to facilitate the description of bone histology and

135 skeletochronology (Turner-Walker \& Mays, 2008).

136 To analyze the histological variability between skeletal elements, bone tissue types and BGMs

137 were studied. The histological descriptions follow the classification of Francillon-Vieillot et al.,

1381990 and de Margerie et al., 2002. The terminology proposed by Prondvai et al., 2014 was

139 employed to describe the different components of the fibrolamellar complex (FLC) (a special

140 case of woven-parallel complex for this authors): "fibrous" or woven bone (WB) and "lamellar"

141 or parallel-fibered bone (PFB). Because the femoral bone histology of the Asiatic wild ass has

142 been previously described in detail (Nacarino-Meneses, Jordana \& Köhler, 2016), only

143 descriptions of the bone tissue of tibiae, metacarpi and metatarsi will be detailed in the present

144 work. Regarding growth marks, we have generally used the term "bone growth mark - BGM",

145 interchangeably for LAGs or annuli, instead of "cyclical growth mark - CGM" because not all

146 the marks identified in the samples have proved to be periodical. Double LAGs or LAGs that

147 split were considered as a single event. BGMs were traced along the cross-sections and

148 superimposition of individuals was performed to identify growth marks that have been erased by

149 the remodeling process or the expansion of the medullary cavity (Woodward, Padian \& Lee,

150 2013). Each BGM circumference was measured with Image $\mathbb{R}$ software to estimate the bones’

151 perimeter at different times during ontogeny and the results were plotted to obtain growth curves

152 for each sample (Bybee, Lee \& Lamm, 2006). The perimeter of the cross-section was also

153 calculated with ImageJ ${ }^{\circledR}$ software in those animals that are still growing (subadult individuals) 
154 to estimate its bone perimeter at the time of death. The perimeter of adult individuals was not 155 determined and only the length of the BGMs identified within the EFS is shown. Because it is 156 generally considered that the presence of EFS indicates the cessation of radial growth in long 157 bones (Huttenlocker, Woodward \& Hall, 2013), the length of the BGMs located in this bone 158 tissue and the perimeter of the cross-section are almost the same value. Thus, the estimation of 159 the cross-section's perimeter in adult specimens does not provide relevant information about the 160 growth of the animal. Furthermore, we calculated the size variation per year of each bone in 161 yearling and adult specimens as the difference of BGMs' perimeters of consecutive annual 162 growth cycles and interpreted it as a proxy of growth rate. Finally, several life history traits were 163 calculated in each bone from the study of CGMs. Age at death of the specimens, was determined 164 as the total number of CGMs present in the bone cortex (Castanet et al., 2004) and compared 165 with the age estimated from teeth. Age at maturity was calculated by counting the CGMs before 166 the deposition of the EFS (Chinsamy \& Valenzuela, 2008; Marín-Moratalla, Jordana \& Köhler, 167 2013) and contrasted with literature data.

\section{RESULTS}

\section{$\underline{\text { 3.1. Bone tissue types }}$}

170

171

172

173

174

175

176

177

178

179

180

All bones of E. hemionus present a well-vascularized FLC that is progressively remodeled during ontogeny. However, the arrangement of the vascular canals embedded in the FLC varies among the bones sampled and in the course of ontogeny. An ontogenetic change in the proportion of the different components of the bone matrix (WB and PFB) has also been noted in some of the limb bones studied, regardless of the orientation of the cutting plane (transversal or longitudinal preparations).

The histology of kulan's femora was previously described in Nacarino-Meneses, Jordana \& Köhler (2016). It consists of a highly vascularized FLC that presents an ontogenetic change in the orientation of the vascular canals to a predominantly circumferential arrangement, along with a decrease in the proportion of the WB of the matrix. The EFS was only indentified in adult stages and remodeling was associated to the course of ontogeny and to mechanical loading. 
181 Tibial cortices consist of laminar bone (Fig. 1A) and remodeling begins early in ontogeny, as the

182 high number of secondary osteons (SO) identified in yearling specimens (Fig. 1B) suggests.

183 Regarding primary bone tissue, the cortical bone of the perinatal individual presents FLC with a

184 high proportion of PFB in the bone matrix (Fig. 1C). The cortex of foals, as well as those of

185 yearling and juvenile individuals, is divided into two well-defined areas that differ in the

186 proportion of this bone matrix component. In these specimens, the laminar bone of the internal

187 cortex presents a higher proportion of PFB than the outer one (Fig. 1A). The EFS is not

188 identified in any of the tibiae analyzed. Instead, several packages of a poorly vascularized

189 lamellar bone that interrupt the FLC matrix, can be recognized in the mid-outer cortex of adult

190 specimens (Fig. 1D). This bone tissue differs from the real EFS (Huttenlocker, Woodward \&

191 Hall, 2013) because it is not restricted to the outermost cortex.

192 Bone tissue and vascular arrangement is very similar in metatarsi and metacarpi. In both skeletal 193 elements, the bone cortex is mainly composed of a FLC with primary osteons (POs) oriented in 194 circular rows (Fig. 2A). The vascular canals of these POs present a larger diameter in the outer

195 half of the cortex than in the inner half (Fig. 2A). Some radial canals are situated in the proximity 196 of the medullary cavity in metacarpal bones (Fig. 2B) whereas metatarsi present several areas 197 with laminar bone (Fig. 2C). Haversian bone is restricted to the posterior side of the cortex in 198 immature kulans but it is more generalized in adult ones. The EFS is identified in the outermost 199 cortex of adult individuals (Fig. 2D).

200 3.2. Bone growth marks

201 Table 2 shows the number of BGMs identified in the different bones of each individual. From 202 foals to adults, all samples present these features, although its number varies among skeletal 203 elements of the same individual and between individuals of the same age category.

204 The presence of a BGM in the middle cortex of tibia, metacarpus and metatarsus (Fig. 3, Table 205 2) of foals (IPS83153 and IPS83154) is surprising. LAGs and annuli are known to be annual and 206 deposited during the unfavorable season (i.e. winter for E. hemionus) in mammals (Köhler et al., 207 2012). Because kulans tend to give birth in summer (Zuckerman, 1952; Nowak, 1999; Feh et al., 208 2001; Feh et al., 2002) and our foals are around six months old (Table 1), the CGM 
209 corresponding to the first winter should be observed in the outermost cortex, not in the mid-

210 cortex (Fig. 3). Therefore, this feature is interpreted as a non-cyclical growth mark and will not

211 be taken into account for age estimation.

212 Yearling specimens (IPS83149, IPS83150 and IPS83151) present a variable number of LAGs.

213 As it is shown in Table 2, one BGM is identified in all skeletal elements of IPS83151, while

214 IPS83149 and IPS83150 present two (Fig. 4). Such variability might be explained by the fact that

215 the first permanent molar is totally unworn in IPS38151 but presents initial wear in IPS83149

216 and IPS83150. Thus, the former might be somewhat younger than the others. Because these

217 specimens are aged as one year, we interpret the most external BGM identified in all bones of

218 IPS83149 and IPS83150 (Fig. 4B, C) as CGM deposited during the first year of life. However,

219 we consider the internal BGM observed in these individuals (Fig. 4B, C), as well as the single

220 BGM identified in the mid-cortex of all bones of IPS83151 (Fig. 4A, D), as a non-cyclical

221 growth mark.

222 Two BGMs are identified in the tibia and the metatarsus of the juvenile individual (IPS83155)

223 while the femur and the metacarpus present only one (Table 2, Fig. 5). In these latter bones, the

224 growth mark appears in the outer cortex (Fig. 5A, C). Because this individual is aged around 2

225 years, we consider that this external BGM is representing the winter growth arrest during its

226 second year of life. The second BGM in the tibia and metatarsus is also found in the external part

227 of the cortex (Fig. 5B, C), so we interpret it as the CGM corresponding to the second winter. On

228 the other hand, superimposition of individuals reveals that the first BGM of these bones (Fig. 5B,

229 C) does not correspond to the CGM identified in yearlings, as it appears more internally within

230 the cortex. This fact suggests that the first winter has not been recorded in this animal and that

231 such internal BGM could be considered as non-cyclical.

232 Wild adult individuals (IPS83876 and IPS83877) also present differences in the number of

233 BGMs between limb bones (Table 2, Fig. 6). Femur, metatarsus and metacarpus of the wild

234 female (IPS83876) show five BGMs while only four BGMs are identified in its tibia (Table 2,

235 Fig. 6A, B, E, F). In the femur, four BGMs lie within the FLC and one within the avascular and

236 highly organized lamellar tissue deposited in the periphery of the bone (EFS) (Table 2, Fig. 6A,

237 B). Metapodial bones, however, present three BGMs within the FLC and two BGMs in the EFS 
238 (Table 2, Fig. 6E, F). The four BGMs found in the tibia are within the FLC, as an EFS is not 239 identified in this bone. On the other hand, the wild male (IPS83877) presents six BGMs in femur 240 and metapodial bones, whereas five BGMs are found in the tibia (Table 2, Fig. 6C, D, G, H).

241 Superimposition of both adult individuals reveals that one BGM has been lost in the femur of the 242 wild male due to bone remodeling (Nacarino-Meneses, Jordana \& Köhler, 2016). This process, 243 however, has not erased the presence of any BGM in the other limb bones studied. Thus, a total 244 of seven BGMs should be counted in the femur of the wild male: five in the FLC (one hidden by 245 secondary osteons) and two in the EFS. Five BGMs, all located in the FLC, are identified in the 246 tibia of this wild male (IPS83877; Table 2, Fig. 6C, D). Finally, four BGMs are found in the FLC 247 and two in the EFS of its metatarsus and metacarpus (Table 2, Fig. 6G, H). The correspondence 248 between the age of both adults and the number of BGMs identified in their limb bones indicates 249 that all these features could be considered as CGMs. However, superimposition suggests that the 250 most internal BGM observed in metapodial bones of wild adults might be a non-cyclical feature, 251 as they are deposited previously to the CGM identified in yearlings.

\section{3.3. Growth curves}

253 Based on the ontogenetic time schedule obtained from the study of the BGMs, we represented 254 the growth curve for the different bones of each specimen (Fig. 7A-D). In these graphs, the 255 perimeter of the bone (outline of the BGM) at different years is plotted against the estimated age. 256 Because the non-cyclical BGM identified in several bones is deposited sometime before the six 257 months of life (Table 2, Fig. 3), it has been considered as time "zero" in the growth curves. The 258 amount of growth in successive years, calculated as a proxy of growth rate, is also represented 259 for yearlings and adult kulans (Fig. 7E-H).

260 In adult individuals, the growth curves, as well as the plots of growth rate estimations, indicates a 261 change in the pace of growth during ontogeny. Figure 7A shows that in both adults, growth of 262 the femur slows down at the fourth year of life and from this time onwards growth is minimal 263 (Fig. 7E). However, this decrease in growth rate takes place at the age of two in tibia, metatarsus 264 and metacarpus (Fig. 7B-D), followed by only minimal growth (Fig. 7F-H). 
265 Figure 7 also reveals differences in growth between captive and wild kulans. The results

266 obtained from the analysis of bone growth cycles of the femur indicate two different growth

267 tendencies with wild specimens growing more slowly than captives (Fig. 7A). While this

268 difference is not perceived in the growth curves of the other limb bones studied (Fig. 7B-D),

269 growth rates of captive individuals are always higher than those of wild kulans in the first year of

270 life (Fig. 7E-H).

271 4. DISCUSSION

272 In the present research, we analyzed the histological variability between limb bones in the extant

273 species Equus hemionus for the first time. Previous studies have addressed this issue in isolated

274 bones of fossil vertebrate species (Horner, de Ricqlès and Padian, 2000; Sander \& Andrássy,

275 2006; Cullen et al., 2014; Martínez-Maza et al., 2014), but only a few have studied the

276 histological variation of bone tissue within the same individual (Horner, de Ricqlès and Padian,

277 1999; García-Martínez et al., 2011; Woodward, Horner \& Farlow, 2014; Cambra-Moo et al.,

278 2015). Our analysis of kulan's bone histology contributes to the knowledge of intraskeletal

279 variability in mammals, providing new and important results that are of interest in different

280 scientific areas. The applicability of histological studies to describe the life history of past

281 animals and their evolutionary trends is well known (Köhler \& Moyà-Solà, 2009; Marín-

282 Moratalla et al., 2011; Martínez-Maza et al., 2014; Woodward et al., 2015). However, many

283 researchers claim that more studies in living taxa are needed to truly understand the correlation

284 between bone histology and the life history strategy of past organisms (Martínez-Maza et al.,

285 2014; Woodward, Horner \& Farlow, 2014; Cambra-Moo et al., 2015; Kolb et al., 2015a; Jordana

286 et al., 2016). The results obtained from the present research will serve as a basis for the inference

287 of life history parameters from the histology of extinct mammal species. Even more,

288 skeletochronological studies of extant species are also of interest in related biological disciplines

289 like Conservation Biology (Chinsamy \& Valenzuela, 2008; García-Martínez et al., 2011; Marín-

290 Moratalla, Jordana \& Köhler, 2013). Nowadays, most of the wild species of the genus Equus are

291 threatened and conservation policies are usually focus on genetic studies of captive individuals

292 (Orlando, 2015). By means of skeletochronology, however, key life history traits such as

293 longevity or age at sexual maturity can be inferred from the bone tissue of wild specimens

294 (Castanet et al., 2004; Marín Moratalla, Jordana \& Köhler, 2013; Jordana et al., 2016). This 
295 information can be later used to calculate demographic parameters (e. g. life expectancy,

296 generation time) that are essential to improve the conservation status of the species in the wild

297 (Feh et al., 2001).

298 The detailed analysis of LAGs and annuli performed in the present research reveals that the 299 number of BGMs recorded by the different limb bones varies within the same specimen (Table 300 2), a fact that has previously been reported for other vertebrate groups (Horner, de Ricqlès \& 301 Padian, 1999; García-Martínez et al., 2011; Cullen et al., 2014; Woodward, Horner \& Farlow, 302 2014). Our results show that the femur registers the highest total number of BGMs, as well as the 303 highest number of these features within the FLC (Table 2). This observation, which has been 304 previously observed in mammals (García-Martínez et al., 2011), is likely related with the fact 305 that the femur is the bone that more tightly correlates with the final size of the individual because 306 it fuses its epiphyses late in ontogeny (Silver, 1969). Furthermore, the total number of CGMs 307 identified in this bone agrees fairly well with the estimated age of the specimens (Table 2), even 308 in the oldest one, which is aged 8 years and present 7 CGMs (one obscured by haversian 309 systems) in the cross-section. This result provides reliability to the estimation of longevity in 310 wild populations of Asiatic wild ass that are known to live around 9 years in the wild (Kaczensky 311 et al., 2015). Horner, de Ricqlès \& Padian, 1999, in their study of Hypacrosaurus stebingeri, 312 suggested that also the tibia is suitable for skeletochronology. However, the presence of many 313 haversian systems in the tibial cortices of hemionus yearlings (Fig. 1B) indicates that it does not 314 provide accurate skeletochronological results in the Asiatic wild ass. The use of metapodial 315 bones in skeletochronology is still a controversial issue. While Horner, de Ricqlés \& Padian, 316 (1999) do not recommend it, for perissodactyls, Martínez-Maza et al. (2014) obtained acceptable 317 results in their histological analysis of the fossil species Hipparion concudense. In artiodactyls, 318 however, it does not work because of the ontogenetically late fusion of metatarsus III and IV that 319 deletes growth structures (M. Köhler, pers. observation). Our results show that these bones 320 record a similar total number of BGMs as the femur (Table 2), although the first BGM identified 321 in these skeletal elements seems to be a non-cyclical BGM (Table 2, Fig. 3-6), a fact that must be 322 taken into account when calculating individual age. This information is especially important for 323 studies that comprise a single individual, to not overestimate the results. Moreover, adult 324 metacarpi and metatarsi show a lower number of BGMs than femora within the FLC (Table 2, 
325 Fig. 6), which contrasts with the results obtained by Martínez-Maza et al. (2014). The presence

326 of BGMs in the fibrolamellar tissue provides important information about the growth and the

327 timing of key life history traits of the species. Because it is deposited during growth

328 (Huttenlocker, Woodward \& Hall, 2013) distance between BGMs has been used to estimate

329 growth rates in extant and extinct mammals (Marín-Moratalla, Jordana \& Köhler, 2013; Kolb et

330 al., 2015b). On the other hand, the number of BGMs within the FLC seems to correlate with the

331 time of sexual maturity in artiodactyls (Marín-Moratalla, Jordana \& Köhler, 2013; Jordana et al.,

332 2016). Therefore, the results obtained from metapodial bones should be used with caution.

333 Despite these drawbacks, the skeletochronological study of metacarpi and metatarsi still provide

334 valuable individual age estimates because they present a similar total number of BGMs as

335 femora (Table 2). This result is especially interesting for the inference of longevity in fossil

336 species, as these bones are the most abundant remains of equids in paleontological sites.

337 Regarding bone tissue types, our results show that femora and tibiae present laminar bone (Fig.

338 1A) while the cortices of metapodial bones are mainly composed of longitudinal POs arranged in

339 circular rows (Fig. 2A) (Francillon-Vieillot et al., 1990). This histological variability, which

340 agrees with previous descriptions of the bone tissue of extant (Enlow \& Brown, 1985; Stover et

341 al., 1992) and fossil (Sander \& Andrássy, 2006; Martínez-Maza et al., 2014) equid species, is

342 likely related with the specific growth rate and biomechanics of each bone (Horner, de Riqclès \&

343 Padian, 1999; de Margerie et al., 2002; de Margerie et al., 2004). On the one hand, the kind of

344 bone matrix is associated with different growth rates (Amprino, 1947; Huttenlocker, Woodward

$345 \&$ Hall, 2013) while the arrangement of the vascular canals is commonly related to mechanical

346 forces (de Margerie, 2002; de Margerie et al., 2002). Furthermore, ontogenetic histological

347 changes regarding bone matrix have been noticed in the different limb bones studied. Our study

348 shows a marked change in the proportion of PFB (Fig. 1A) within the FLC matrix in tibiae of

349 subadult kulans. Bone matrix change, along with a modification of the orientation of the vascular

350 canals, has also been observed in femora of E. hemionus (Nacarino-Meneses, Jordana \& Köhler,

351 2016). These histological modifications are likely related to both the changes in loadings (Firth,

352 2006) and in growth rate (Peters, 1983) that foals experience at the moment of birth.

353 Amongst all bone tissue types, the occurrence of EFS in vertebrates is a controversial issue.

354 Traditionally, its deposition has been interpreted as the attainment of skeletal maturity (Cormack, 
355 1987; Chinsamy-Turan, 2005; Woodward, Padian \& Lee, 2013; Martínez-Maza et al., 2014;

356 Amson et al., 2015; Kolb et al., 2015b) but recent studies have shown that, at least in mammals,

357 it might also be related with the onset of sexual maturity of the species (Klevezal, 1996; Marín-

358 Moratalla, Jordana \& Köhler, 2013; Jordana et al., 2016). Growth studies have been shown to

359 provide good estimations of these traits in fossil species (Lee et al., 2013). Our results indicate

360 that the EFS is deposited after epiphyseal fusion in all bones and at a later time in the male than

361 in the female (Table 3, Fig. 7). Actually, in most of the bones analyzed, the time of fusion of

362 both epiphyses agrees with an important drop in the rate of radial growth (inflection point in the

363 growth curves, Fig. 7) and does not match the time of deposition of the EFS. Concretely in the

364 femur, which epiphyses are fused at the age of three (Silver, 1969), the EFS of the wild female is

365 deposited in the fourth year of life while in the wild male it appears at the age of six (Table 3;

366 Fig. 7). In metapodials, the EFS appears after the third year in the female and after the fourth

367 year in the male (Table 3, Fig. 7). These skeletal elements are completely fused at the age of two

368 (Silver, 1969). The correspondence between the pronounced decrease in periosteal growth rate

369 and the age of epiphyseal fusion (Silver, 1969) (Table 3) suggests the decrease in periosteal

370 growth rate to be a good indicator of the end of longitudinal growth in the respective bone.

371 However, the deposition of the EFS some time after growth decline (Fig. 7) indicates that the

372 bone shaft continues growing at minimal rates over some time until full radial growth is achieved

373 (Huttenlocker, Woodward \& Hall, 2013). This decoupling between longitudinal and radial

374 growth suggests that inferences of skeletal maturity from the time of deposition of the EFS in

375 equids might be incorrect. However, the presence of the EFS in femora agrees fairly well with

376 the age at first reproduction reported for E. hemionus (Table 3; Kaczensky et al., 2015). In

377 general terms, the femur in mammals presents the longest time of development with the latest

378 epiphyseal fusion (Silver, 1969). Thus, its histological structure should provide the best record of

379 life history events. It is known that although kulans are sexually mature at their second or third

380 year of life (Nowak, 1999), they delay some years its first mating (Kaczensky et al., 2015).

381 Hence, our results provide histological evidence for this well-known behavior in equids

382 (Fielding, 1988; Monfort, Arthur \& Wildt, 1994).

383 Finally, the growth analysis has also revealed a high inter-individual variability in size (Fig. 7)

384 that should be taken into account when retrocalculating lost CGMs. Our results, although 
385 obtained from a relatively small sample size, show different femoral growth tendencies between

386 wild and captive individuals (Fig. 7A) and a higher growth rate in captive exemplars than in wild

387 ones during the first year of life (Fig. 7E-H). These differences, that reflect the influence of the

388 habitat in the life history of the species, have been previously reported for mammals (Marín-

389 Moratalla, Jordana \& Köhler, 2013) and alligators (Woodward, Horner \& Farlow, 2014) and are

390 related with the constant food supply and care that captive animals experience during their life

391 (Asa, 2010). To obtain the most accurate data, we propose to study wild animals when possible

392 to avoid overestimation of growth rates for the species under study.

\section{5. CONCLUSIONS}

394 Our study analyzes the histological variation between different limb bones of the Asiatic wild 395 ass. Our research provides evidence that the femur is the most reliable bone for skeletochronological studies in equids, although metapodial bones also provide good individual age estimations. The use of tibiae, however, is not recommended for this group due to the high presence of secondary osteons observed in early ontogenetic stages. Furthermore, all bones present histological changes regarding the proportions of bone matrix components and / or the arrangement of vascular canals in the course of ontogeny. Finally, the presence of an EFS in the outermost cortex of adult femora is likely related to the reproductive maturity of the species (first reproduction) than to skeletal maturity. Skeletal maturity, however, is recorded in growth curves as a significant drop in periosteal growth rate.

\section{ACKNOWLEDGMENTS}

405 We are grateful to Thomas Kaiser for loans of the collection of the Zoological Institute of 406 Hamburg University (Hamburg, Germany) and to Renate Schafberg for permission to cut the 407 adult kulan bones from the collections housed at Museum of Domesticated Animals of the 408 Martin-Luther-University Halle-Wittenberg (Halle, Saale, Germany). We are indebt to Gemma 409 Prats-Muñoz and Luis Gordon for preparing the thin sections of the study. Finally, we 410 acknowledge William Jungers for handling the article as editor of PeerJ and Clara Stefen, Jorge 411 Cubo and Tim Bromage for their useful reviews, which greatly improve an earlier version of the 412 manuscript. 


\section{REFERENCES}

414 Asa CS. 2010. Reproductive physiology. In: Kleiman DG, Thompson KV, Kirk-Baer C, eds.

415 Wild Mammals in Captivity. London: The University of Chicago Press, 219-252.

416 Amson E, Kolb C, Scheyer TM, Sánchez-Villagra MR. 2015. Growth and life history of Middle

417 Miocene deer (Mammalia, Cervidae) based on bone histology. Comptes Rendus Palevol 14:637-

418 645. DOI: 10.1016/j.crpv.2015.07.001.

419 Bybee PJ, Lee AH, Lamm ET. 2006. Sizing the Jurassic theropod dinosaur Allosaurus: assessing 420 growth strategy and evolution of ontogenetic scaling limbs. Journal of Morphology 267:347-35.9 421 DOI: 10.1002/jmor.10406.

422 Cambra-Moo O, Nacarino-Meneses C, Díaz-Güemes I, Enciso S, García Gil O, Llorente 423 Rodríguez L, Rodríguez Barbero MA, de Aza AH, González Martín A. 2015. Multidisciplinary 424 characterization of the long-bone cortex growth patterns through sheep's ontogeny. Journal of 425 Structural Biology 191:1-9. DOI: 10.1016/j.jsb.2015.06.013.

426 Castanet J. 2006. Time recording in bone microstructures of endothermic animals; functional 427 relationships. Comptes Rendus Palevol 5:629-636. DOI: 10.1016/j.crpv.2005.10.006.

428 Castanet J, Francillon-Vieillot H, Meunier FJ, de Ricqlès A. 1993. Bone and individual aging. In: 429 Hall BK, ed. Bone, vol. 7. London: CRC Press, 245-283.

430 Castanet J, Croci S, Aujard F, Perret M, Cubo J, de Margerie E. 2004. Lines of arrested growth 431 in bone and age estimation in a small primate: Microcebus murinus. Journal of Zoology 263:31432 39. DOI: 10.1017/S0952836904004844.

433 Chinsamy-Turan A. 2005. The Microstructure of Dinosaur Bone. Baltimore and London: The 434 Johns Hopkins University Press.

435 Chinsamy A, Valenzuela N. 2008. Skeletochronology of the endangered side-neck turtle, 436 Podocnemis expansa. South African Journal of Science 104:311-314.

437 Cormack D. 1987. Ham's Histology. Philadelphia: JC Lippincott Williams and Wilkins. 
438 Cullen TM, Evans DC, Ryan MJ, Currie PJ, Kobayashi Y. 2014. Osteohistological variation in 439 growth marks and osteocyte lacunar density in a theropod dinosaur (Coelurosauria:

440 Ornithomimidae). BMC Evolutionary Biology 14:231. DOI: 10.1186/s12862-014-0231-y.

441 Downer CC. 2014. The horse and burro as positively contributing returned natives in North 442 America. American Journal of Life Sciences 2:5-23. DOI: 10.11648/j.ajls.20140201.12

443 Enlow DH, Brown SO. 1958. A Comparative Histological study of Fossil and Recent Bone 444 Tissues. Part III. Texas Journal of Science 10:187-230.

445 Feh C, Munkhtuya B, Enkhbold S, Sukhbaatar T. 2001. Ecology and social structure of the Gobi 446 khulan Equus hemionus subsp. in the Gobi B National Park, Mongolia. Biological Conservation 447 10: 51-61. DOI:10.1016/S0006-3207(01)00051-9.

448 Feh C, Shah N, Rowen M, Reading R, Goyal SP. 2002. Status and Action Plan for the Asiatic 449 Wild Ass (Equus hemionus). In: Mohelman PD, ed. Zebras, Asses and Horses. Status Survey and 450 Conservation Action Plan. Gland and Cambridge: IUCN/SS Equid Specialist Group, 62-71.

451 Fielding, D. 1988. Reproductive characteristics of the jenny donkey-Equus asinus: A review. 452 Tropical Animal Health and Production 20:161-166. DOI: 10.1007/BF02240085.

453 Firth EC. 2006. The response of bone, articular cartilage and tendon to exercise in the horse. 454 Journal of Anatomy 208:513-526. DOI: 10.1111/j.1469-7580.2006.00547.x.

455 Forstén A. 1992. Mitochondrial-DNA time-table and the evolution of Equus: comparison of 456 molecular and paleontological evidence. Annales Zoologici Fennici 28:301-309.

457 Francillon-Vieillot H, de Buffrénil V, Castanet J, Géraudie J, Meunier FJ, Sire JY, Zylberberg L, 458 de Ricqlès A. 1990. Microstructure and mineralization of vertebrate skeletal tissues. In: Carter 459 JG, ed. Skeletal Biomineralization: Patterns, Processes and Evolutionary Trends. New York: 460 Van Nostrand Reinhold, 471-530.

461 García-Martínez R, Marín-Moratalla N, Jordana X, Köhler M. 2011. The ontogeny of bone 462 growth in two species of dormice: Reconstructing life history traits. Comptes Rendus Palevol 463 10:489-498. DOI: 10.1016/j.crpv.2011.03.011. 
464 Horner JR, de Ricqlès A, Padian K. 1999. Variation in dinosaur skeletochronology indicators: 465 implications for age assessment and physiology. Paleobiology 25:295-304.

466 Horner JR, de Ricqlès A, Padian K. 2000. Long bone histology of the hadrosaurid dinosaur 467 Maiasaura peeblesorum: growth dynamics and physiology based on an ontogenetic series of 468 skeletal elements. Journal of Vertebrate Paleontology 20:115-129. DOI: 10.1671/0272469 4634(2000)020[0115:LBHOTH]2.0.CO;2

470 Huttenlocker AK, Woodward HN, Hall BK. 2013. The biology of Bone. In: Padian K, Lamm 471 ET, eds. Bone Histology of Fossil Tetrapods. Berkeley, Los Angeles, London: University of 472 California Press, 13-34.

473 Jordana X, Marín-Moratalla N, Moncunill-Solé B, Nacarino-Meneses C, Köhler M. 2016.

474 Ontogenetic changes in the histological features of zonal bone tissue of ruminants: a quantitative 475 approach. Comptes Rendus Palevol 15:265-276. DOI: 10.1016/j.crpv.2015.03.008.

476 Kaczensky P, Lkhagvasuren B, Pereladova O, Hemami M, Bouskila, A. 2015. Equus hemionus. 477 The IUCN Red List of Threatened Species 2015:e.T7951A45171204. DOI:

478 10.2305/IUCN.UK.2015-4.RLTS.T7951A45171204.en

479 Klevezal G.A. 1996. Recording Structures of Mammals: Determination of Age and 480 Reconstruction of Life History. Rotterdam: AA Balkema.

481 Köhler M, Moyà-Solà S. 2009. Physiological and life history strategies of a fossil large mammal 482 in a resource-limited environment. Proceedings of the National Academy of Sciences of the 483 United States of America. 106:20354-20358. DOI: 10.1073/pnas.0813385106

484 Köhler M. 2010. Fast or slow? The evolution of life history traits associated with insular 485 dwarfing. In: Pérez-Mellado V, Ramon MM, eds. Islands and Evolution. Maó: Institut Menorquí 486 d'Estudis, Recerca 19, 261-279.

487 Köhler M, Marín-Moratalla N, Jordana X, Aanes R. 2012. Seasonal bone growth and physiology 488 in endotherms shed light on dinosaur physiology. Nature 487, 358-361. DOI $48910.1038 /$ nature1 1264. 
490 Kolb C, Scheyer TM, Veitschegger K, Forasiepi AM, Amson E, Van der Geer AAE, Van den

491 Hoek Ostende LW, Hayashi S, Sánchez-Villagra MR. 2015a. Mammalian bone paleohistology: a 492 survey and new data with emphasis on island forms. PeerJ 3:e1358 DOI 10.7717/peerj.1358.

493 Kolb C, Scheyer TM, Lister AM, Azorit C, De Vos J, Schlingemann MAJ, Rössner GE, 494 Monaghan NT, Sánchez-Villagra MR. 2015b. Growth in fossil and extant deer and implications 495 for body size and life history evolution. BMC Evolutionary Biology 15:1-15 DOI $49610.1186 / \mathrm{s} 12862-015-0295-3$.

497 Lamm ET. 2013. Preparation and Sectioning of Specimens. In: Padian K, Lamm ET, eds. Bone 498 Histology of Fossil Tetrapods. Berkeley, Los Angeles, London: University of California Press, $49955-160$.

500 Lee AH, Huttenlocker AK, Padian K, Woodward HN. 2013. In: Padian K, Lamm ET, eds. Bone 501 Histology of Fossil Tetrapods. Berkeley, Los Angeles, London: University of California Press, $502 \quad 217-251$.

503 Lkhagvasuren D, Ansorge H, Samiya R, Schafberg R, Stubbe A, Stubbe M. 2013. Age 504 determination of the Mongolian wild ass (Equus hemionus, Pallas 1775) by the dentition patterns 505 and annual lines in the tooth cementum. Journal of Species Research 2:85-90. DOI:

506 10.12651/JSR.2013.2.1.085.

507 MacFadden BJ. 1992. Fossil horses. Systematics, Paleobiology, and Evolution of the Family 508 Equidae. Cambridge, New York, Melbourne, Madrid: Cambridge University Press.

509 MacFadden BJ. 2005. Fossil Horses - Evidence of evolution. Science 307:1728-1730. DOI: $510 \quad 10.1126 /$ science. 1105458.

511 de Margerie E, Cubo J, Castanet J. 2002. Bone typology and growth rate: testing and quantifying 512 “Amprino’s rule” in the mallard (Anas platyrhynchos). Comptes Rendus Biologies 325:221-230. 513 DOI: 10.1016/S1631-0691(02)01429-4.

514 de Margerie E, Robin JP, Verrier D, Cubo J, Groscolas R, Castanet J. 2004. Assessing a 515 relationship between bone microstructure and growth rate: a fluorescent labeling study in the 
516 king penguin chick (Aptenodytes patagonicus). Journal of Experimental Biology 207:869-879. 517 DOI: $10.1242 /$ jeb.00841.

518 Marín-Moratalla N, Jordana X, García-Martínez R, Köhler M. 2011. Tracing the evolution of 519 fitness components in fossil bovids under different selective regimes. Comptes Rendus Palevol 520 10:469-478. DOI: 10.1016/j.crpv.2011.03.007.

521 Marín-Moratalla N, Jordana X, Köhler M. 2013. Bone histology as an approach to providing data 522 on certain key life history traits in mammals: Implications for conservation biology. Mammalian 523 Biology 78:422-429. DOI: 10.1016/j.mambio.2013.07.079.

524 Marín-Moratalla N, Cubo J, Jordana X, Moncunill-Solé B, Köhler M. 2014. Correlation of 525 quantitative bone histology data with life history and climate: a phylogenetic approach.

526 Biological Journal of the Linnean Society 112:678-687. DOI: 10.1111/bij.12302.

527 Martínez-Maza C, Alberdi MT, Nieto-Diaz M, Prado JL. 2014. Life-History Traits of the 528 Miocene Hipparion concudense (Spain) Inferred from Bone Histological Structure. Plos One 529 9:e103708. DOI: 10.1371/journal.pone.0103708.

530 Moncunill-Solé B, Orlandi-Oliveras G, Jordana X, Rook L, Köhler M. 2016. First approach of 531 the life history of Prolagus apricenicus (Ochotonidae, Lagomorpha) from Terre Rosse sites 532 (Gargano, Italy) using body mass estimation and paleohistological analysis. Comptes Rendus 533 Palevol 15:235-245. DOI: 10.1016/j.crpv.2015.04.004.

534 Monfort, SL, Arthur NP, Wildt DE. 1994. Reproduction in the Przewalski's horse. In: Boyde L, 535 Houpt KA, eds. Przewalski's horse. The history and biology of an endangered species. Albany: 536 State University of New York Press, 173-194.

537 Nacarino-Meneses C, Jordana X, Köhler M. 2016. First approach to bone histology and 538 skeletochronology of Equus hemionus. Comptes Rendus Palevol 15:277-287. DOI:

539 10.1016/j.crpv.2015.02.005.

540 Nowak RM. 1999. Walker's Mammals of the World, $6^{\text {th }}$ ed. Baltimore and London: The Johns 541 Hopkins University Press. 
542 Orlandi-Oliveras G, Jordana X, Moncunill-Solé B, Köhler M. 2016. Bone histology of the giant

543 fossil dormouse Hypnomys onicensis (Gliridae, Rodentia) from Balearic Islands. Comptes

544 Rendus Palevol 15:247-253. DOI: 10.1016/j.crpv.2015.05.001.

545 Orlando L. 2015. Equids. Current biology 25:R973-R978. DOI: 10.1016/j.cub.2015.09.005.

546 Padian K, de Ricqlès A, Horner JR. 2001. Dinosaurian growth rates and bird origins. Nature 547 412:405-408. DOI: 10.1038/35086500.

548 Peabody FE. 1961. Annual growth zones in living and fossil vertebrates. Journal of Morphology 549 108:11-62. DOI: 10.1002/jmor.1051080103.

550 Peters RH. 1983. The ecological implications of body size. Cambridge, New York, Victoria: 551 Cambridge University Press.

552 Prondvai E, Stein KHW, de Ricqlès A, Cubo J. 2014. Development-based revision of bone tissue 553 classification: the importance of semantics for science. Biological Journal of the Linnean Society 554 112:799-816. DOI: 10.1111/bij.12323.

555 Reading RP, Mix HM, Lhagvasuren B, Feh C, Kane DP, Dulamtseren S, Enkhbold S. 2001. 556 Status and distribution of khulan (Equus hemionus) in Mongolia. Journal of Zoology 254:381557 389. DOI: 10.1017/S0952836901000887.

558 Sander PM, Andrássy P. 2006. Lines of arrested growth and long bone histology in Pleistocene 559 large mammals from Germany: What do they tell us about dinosaur physiology?

560 Palaeontographica Abteilung A 277:143-159.

561 Schöpke K, Stubbe A, Stubbe M, Batsaikhan N, Schafberg R. 2012. Morphology and variation 562 of the Asiatic wild ass. Erforschung biologischer Ressourcen der Mongolei. 12:77-84.

563 Silver IA. 1969. The ageing of domestic mammals. In: Brothwell D, Higgs E, eds. Science in 564 Archaeology. New York: Basic Books, 250-268.

565 Stein K, Prondvai E. 2014. Rethinking the nature of fibrolamellar bone: an integrative biological 566 revision of sauropod plexiform bone formation. Biological reviews 89:24-47. DOI:

$56710.1111 /$ brv.12041. 
568 Steiner CC, Ryder OA. 2011. Molecular phylogeny and evolution of the Perissodactyla.

569 Zoological Journal of the Linnean Society 163:1289-1303. DOI: 10.1111/j.1096-

$570 \quad 3642.2011 .00752 . x$.

571 Stover SM, Pool RR, Martin RB, Morgan P. 1992. Histological features of the dorsal cortex of

572 the third metacarpal bone mid-diaphysis during postnatal growth in thoroughbred horses. Journal 573 of Anatomy 181:455-469.

574 Turner-Walker G, Mays S. Histological Studies on Ancient Bone. In: Pinhasi R, Mays S, eds.

575 Advances in Human Palaeopathology. Chichester: John Wiley \& Sons, Ltd, 121-146.

576 Woodward HN, Padian K, Lee AH. 2013. Skeletochronology. In: Padian K, Lamm ET, eds.

577 Bone Histology of Fossil Tetrapods. Berkeley, Los Angeles, London: University of California

578 Press, 195-216.

579 Woodward HN, Horner JR, Farlow JO. 2014. Quantification of intraskeletal histovariability in

580 Alligator mississippiensis and implications for vertebrate osteohistology. PeerJ 2:e422. DOI:

$58110.7717 /$ peerj.422.

582 Woodward HN, Freedman Fowler EA, Farlow JO, Horner JR. 2015. Maiasaura, a model 583 organism for extinct vertebrate population biology: a large sample statistical assessment of 584 growth dynamics and survivorship. Paleobiology 41:503-527. DOI: 10.1017/pab.2015.19.

585 Zuckerman S. 1952. The breeding season of mammals in captivity. Proceedings of the 586 Zoological Society of London 122:827-950. DOI: 10.1111/j.1096-3642.1952.tb00251.x. 


\section{Table 1 (on next page)}

Sample studied.

M: male; F: female; Fe: femur; Ti: tibia; Mc: metacarpus; Mt: metatarsus. 


\begin{tabular}{|l|l|l|l|l|l|l|}
\hline Individual & $\begin{array}{l}\text { Estimated } \\
\text { age }\end{array}$ & \multicolumn{1}{|c|}{$\begin{array}{c}\text { Age } \\
\text { group }\end{array}$} & \multicolumn{1}{|c|}{ Habitat } & Sex & $\begin{array}{l}\text { Bones } \\
\text { studied }\end{array}$ & \multicolumn{1}{|c|}{ Collection } \\
\hline IPS83152 & $<3$ weeks & Perinatal & $\begin{array}{l}\text { Hagenbeck } \\
\text { Zoo }\end{array}$ & - & $\begin{array}{l}\text { Fe, Ti, } \\
\mathrm{Mc}, \mathrm{Mt}\end{array}$ & $\begin{array}{l}\text { Zoological Institute of Hamburg } \\
\text { University (Hamburg, Germany) }\end{array}$ \\
\hline IPS83153 & 0.5 years & Foal & $\begin{array}{l}\text { Hagenbeck } \\
\text { Zoo }\end{array}$ & $\mathrm{M}$ & $\begin{array}{l}\mathrm{Fe}, \mathrm{Ti}, \\
\mathrm{Mc}, \mathrm{Mt}\end{array}$ & $\begin{array}{l}\text { Zoological Institute of Hamburg } \\
\text { University (Hamburg, Germany) }\end{array}$ \\
\hline IPS83154 & 0.5 years & Foal & $\begin{array}{l}\text { Hagenbeck } \\
\text { Zoo }\end{array}$ & $\mathrm{M}$ & $\begin{array}{l}\mathrm{Fe}, \mathrm{Ti}, \\
\mathrm{Mc},\end{array}$ & $\begin{array}{l}\text { Zoological Institute of Hamburg } \\
\text { University (Hamburg, Germany) }\end{array}$ \\
\hline IPS83149 & 1 year & Yearling & $\begin{array}{l}\text { Hagenbeck } \\
\text { Zoo }\end{array}$ & - & $\begin{array}{l}\mathrm{Fe}, \mathrm{Ti}, \\
\mathrm{Mc}, \mathrm{Mt}\end{array}$ & $\begin{array}{l}\text { Zoological Institute of Hamburg } \\
\text { University (Hamburg, Germany) }\end{array}$ \\
\hline IPS83150 & 1 year & Yearling & $\begin{array}{l}\text { Hagenbeck } \\
\text { Zoo }\end{array}$ & - & $\begin{array}{l}\mathrm{Fe}, \mathrm{Ti}, \\
\mathrm{Mc}, \mathrm{Mt}\end{array}$ & $\begin{array}{l}\text { Zoological Institute of Hamburg } \\
\text { University (Hamburg, Germany) }\end{array}$ \\
\hline IPS83151 & 1 year & Yearling & $\begin{array}{l}\text { Hagenbeck } \\
\text { Zoo }\end{array}$ & - & $\begin{array}{l}\mathrm{Fe}, \mathrm{Ti}, \\
\mathrm{Mc}, \mathrm{Mt}\end{array}$ & $\begin{array}{l}\text { Zoological Institute of Hamburg } \\
\text { University (Hamburg, Germany) }\end{array}$ \\
\hline IPS83155 & 2 years & Juvenile & $\begin{array}{l}\text { Hagenbeck } \\
\text { Zoo }\end{array}$ & $\mathrm{F}$ & $\begin{array}{l}\mathrm{Fe}, \mathrm{Ti}, \\
\mathrm{Mc}, \mathrm{Mt}\end{array}$ & $\begin{array}{l}\text { Zoological Institute of Hamburg } \\
\text { University (Hamburg, Germany) }\end{array}$ \\
\hline IPS83876 & 4.5 years & Adult & Gobi desert & $\mathrm{F}$ & $\begin{array}{l}\mathrm{Fe}, \mathrm{Ti}, \\
\mathrm{Mc}, \mathrm{Mt}\end{array}$ & $\begin{array}{l}\text { Museum of Domesticated Animals } \\
\text { (Halle, Germany) }\end{array}$ \\
\hline IPS83877 & 8 years & Adult & Gobi desert & $\mathrm{M}$ & $\begin{array}{l}\mathrm{Fe}, \mathrm{Ti}, \\
\mathrm{Mc}, \mathrm{Mt}\end{array}$ & $\begin{array}{l}\text { Museum of Domesticated Animals } \\
\text { (Halle, Germany) }\end{array}$ \\
\hline
\end{tabular}




\section{Table 2 (on next page)}

Number of bone growth marks (BGMs) identified in each cross-section.

M: male; F: female; FLC: number of BGMs identified within the fibrolamellar complex; EFS:

number of BGMs identified within the external fundamental system. Asterisk $(*)$ indicates that the most internal BGM has been considered as a non-cyclical BGM. 


\begin{tabular}{|c|c|c|c|c|c|c|c|c|c|c|c|c|c|c|c|}
\hline \multirow[b]{2}{*}{ Individual } & \multirow[b]{2}{*}{$\begin{array}{c}\text { Estimated } \\
\text { age }\end{array}$} & \multirow[b]{2}{*}{$\begin{array}{l}\text { Age } \\
\text { group }\end{array}$} & \multirow[b]{2}{*}{ Sex } & \multicolumn{3}{|c|}{ Femur } & \multicolumn{3}{|c|}{ Tibia } & \multicolumn{3}{|c|}{ Metacarpus } & \multicolumn{3}{|c|}{ Metatarsus } \\
\hline & & & & $\underset{\text { U }}{U}$ & $\begin{array}{l}\Omega \\
\frac{I}{I I}\end{array}$ & 豞 & $\underset{U}{U}$ & $\underset{I}{\Lambda}$ & 苟 & $\underset{\mid}{\mathcal{U}}$ & $\underset{\Lambda}{\mathbb{I}}$ & 吾 & $\underset{ت}{U}$ & $\begin{array}{l}\boldsymbol{L} \\
\frac{1}{I}\end{array}$ & $\stackrel{\pi}{0}$ \\
\hline IPS83152 & $<3$ weeks & Perinatal & - & 0 & - & $\mathbf{0}$ & 0 & - & $\mathbf{0}$ & 0 & - & $\mathbf{0}$ & 0 & - & $\mathbf{0}$ \\
\hline IPS83153 & 0.5 years & Foal & $\mathrm{M}$ & 0 & - & $\mathbf{0}$ & 1 & - & $1 *$ & 1 & - & $1 *$ & 1 & - & $1 *$ \\
\hline IPS83154 & 0.5 years & Foal & $\mathrm{M}$ & 0 & - & $\mathbf{0}$ & 1 & - & $1 *$ & 1 & - & $1 *$ & - & - & - \\
\hline IPS83149 & 1 year & Yearling & - & 2 & - & 2* & 2 & - & $2 *$ & 2 & - & $2 *$ & 2 & - & 2* \\
\hline IPS83150 & 1 year & Yearling & - & 2 & - & $2 *$ & 2 & - & 2* & 2 & - & $2 *$ & 2 & - & $2 *$ \\
\hline IPS83151 & 1 year & Yearling & - & 1 & - & $1 *$ & 1 & - & $1 *$ & 1 & - & $1 *$ & 1 & - & 1* \\
\hline IPS83155 & 2 years & Juvenile & $\mathrm{F}$ & 1 & - & 1 & 2 & - & $2 *$ & 1 & - & 1 & 2 & - & $2 *$ \\
\hline IPS83876 & 4.5 years & Adult & $\mathrm{F}$ & 4 & 1 & 5 & 4 & - & 4 & 3 & 2 & $5 *$ & 3 & 2 & $5 *$ \\
\hline IPS83877 & 8 years & Adult & $\mathrm{M}$ & 4 & 2 & 6 & 5 & - & 5 & 4 & 2 & 6* & 4 & 2 & 6* \\
\hline
\end{tabular}

1 


\section{Table 3 (on next page)}

Age of deposition of the external fundamental system (EFS) in the limb bones of adult kulans and time of several biological traits in equids obtained from the literature.

Age of epiphyseal fusion (Silver, 1963) is indicated for the closely related species Equus caballus while age at sexual maturity (Nowak, 1999) and age at first reproduction (Kaczensky et al., 2015) is reported for Equus hemionus. All data are expressed in years. F: femur; T: tibia; Mc: metacarpus; Mt: metatarsus. 


\begin{tabular}{|l|c|c|c|c|c|c|c|c|c|c|}
\cline { 2 - 11 } \multicolumn{1}{c|}{} & \multicolumn{4}{c|}{ EFS } & \multicolumn{4}{c|}{ Epiphyseal fusion } & Sexual & Age at first \\
\cline { 2 - 11 } \multicolumn{1}{c|}{} & $\mathrm{F}$ & $\mathrm{T}$ & $\mathrm{Mc}$ & $\mathrm{Mt}$ & $\mathrm{F}$ & $\mathrm{T}$ & $\mathrm{Mc}$ & $\mathrm{Mt}$ & maturity & reproduction \\
\hline Female & 4 & - & 3 & 3 & $3-3.5$ & $3-3.5$ & $1.25-1.5$ & $1.3-1.6$ & 2 & 3 \\
\hline Male & 6 & - & 4 & 4 & $3-3.5$ & $3-3.5$ & $1.25-1.5$ & $1.3-1.6$ & 3 & 5 \\
\hline
\end{tabular}

1 


\section{Figure 1}

Tibial bone histology of the Asiatic wild ass.

A) Detail of the lateral cortex of the foal IPS83153, showing two areas that differ in the proportions of the parallel-fibered component (PFB) of the bone matrix. B) Haversian systems in the anterior cortex of the yearling IPS83150. C) Anterior cortex of the newborn individual (IPS83152) with a high proportion of parallel-fibered component (PFB) in its bone matrix. D) Packages of lamellar bone within the fibrolamellar complex in the anterior cortex of the wild male (IPS83877). HS: haversian systems; LB: lamellar bone; PFB: parallel-fibered bone. Scale bars: 1 millimeter. All images were obtained under polarized light with a $1 / 4 \lambda$ filter.
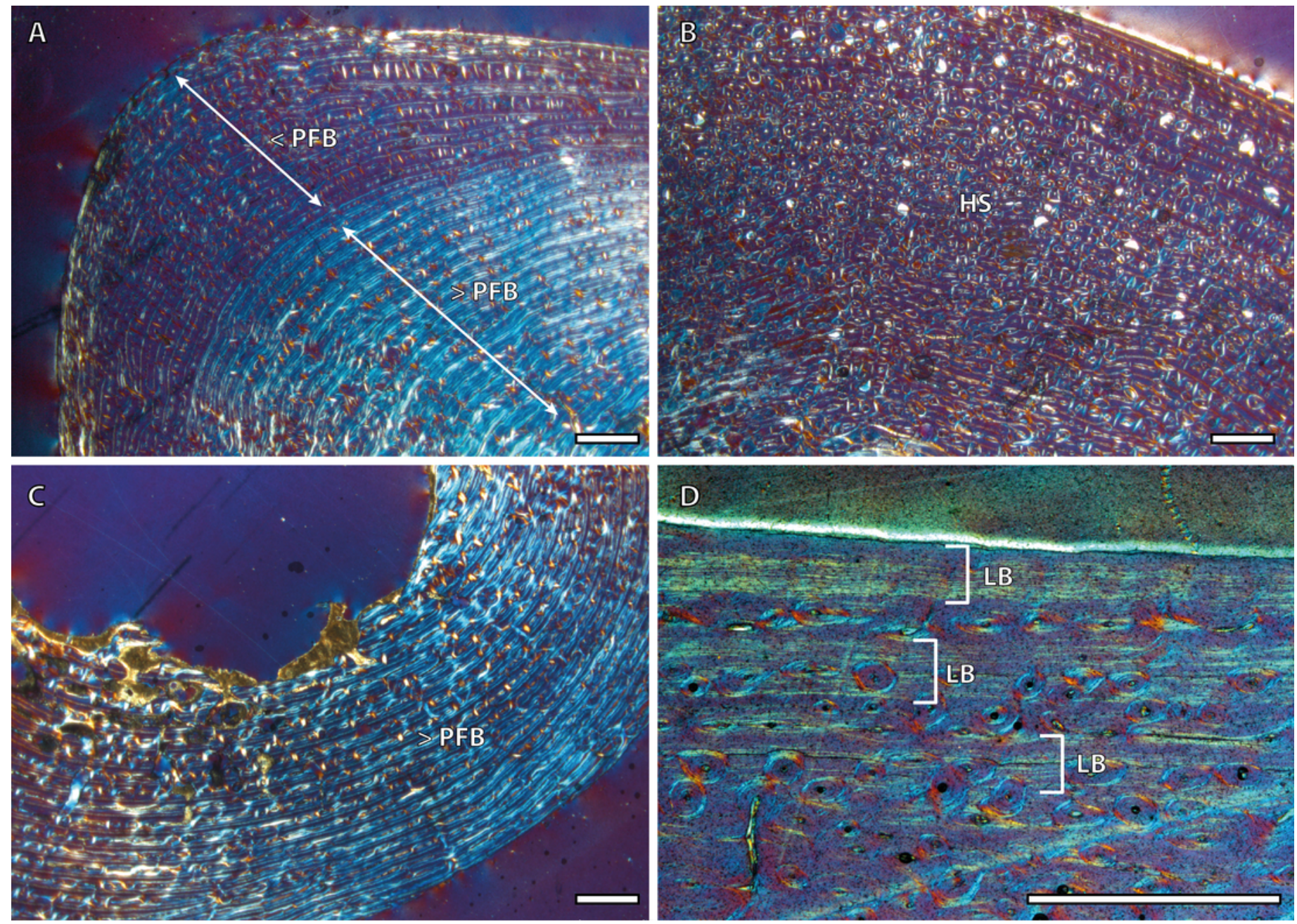


\section{Figure 2}

Metapodial bone histology of the Asiatic wild ass.

A) Anterior metatarsal cortex of the yearling IPS83149, showing a fibrolamellar complex with primary osteons oriented in circular rows. B) Radial canals in the metacarpus of the yearling IPS83150. C) Circular canals in the metatarsus of the foal IPS83153. D) Detail of the external fundamental system in the metatarsus of the wild female IPS83876. EFS: external fundamental system; FLC: fibrolamellar complex. Scale bars: 1 millimeter. All images were obtained under polarized light with a $1 / 4 \lambda$ filter.
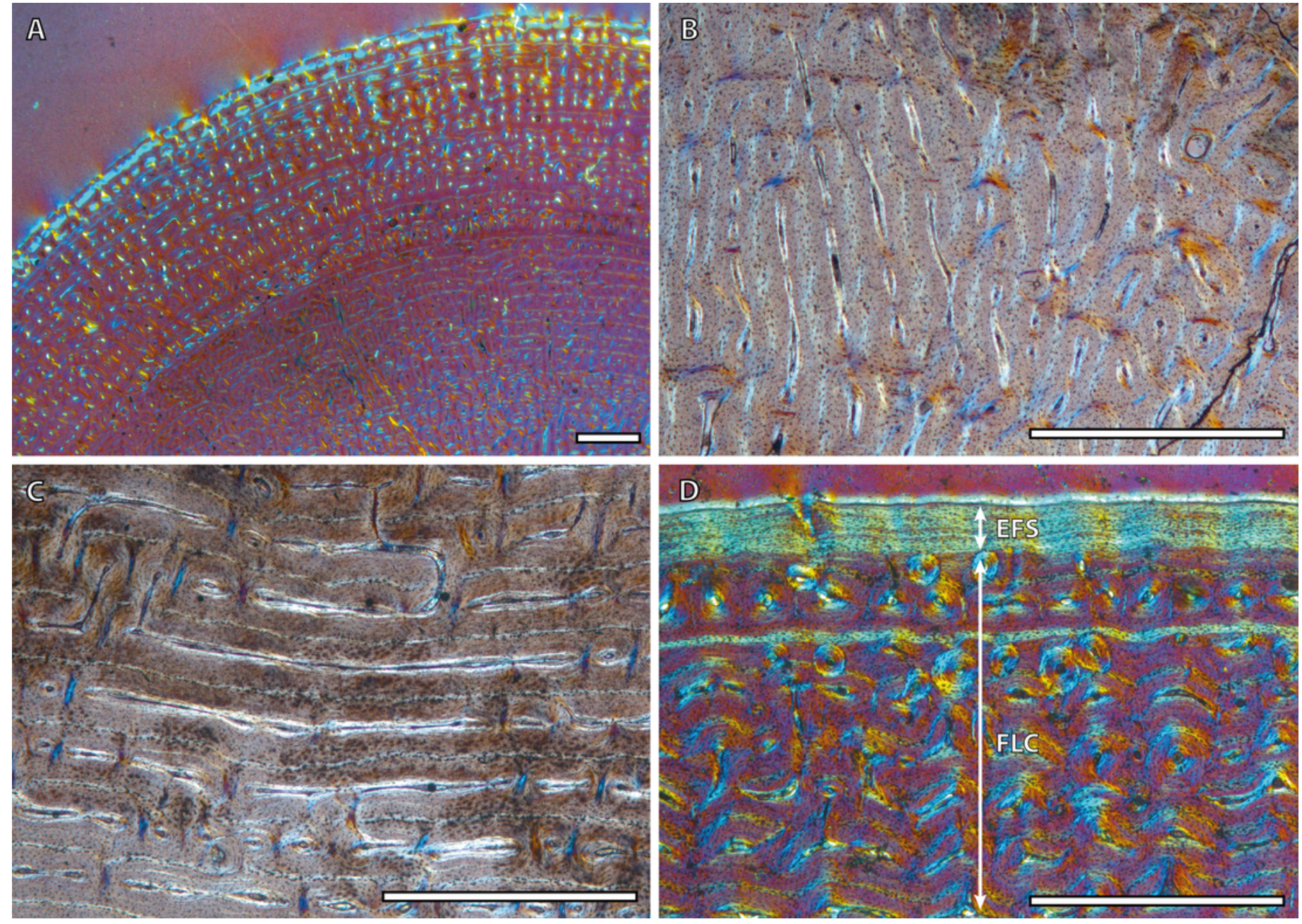


\section{Figure 3}

Bone growth marks in foal kulans.

A) BGM in the lateral side of the tibia (IPS83154). B) BGM in the anterior cortex of the metacarpus (IPS83153). C) BGM in the anterior side of the metatarsus (IPS83153). White arrows indicate bone growth marks. Scale bar: 1 millimeter. All images were obtained under polarized light with a $1 / 4 \lambda$ filter. 

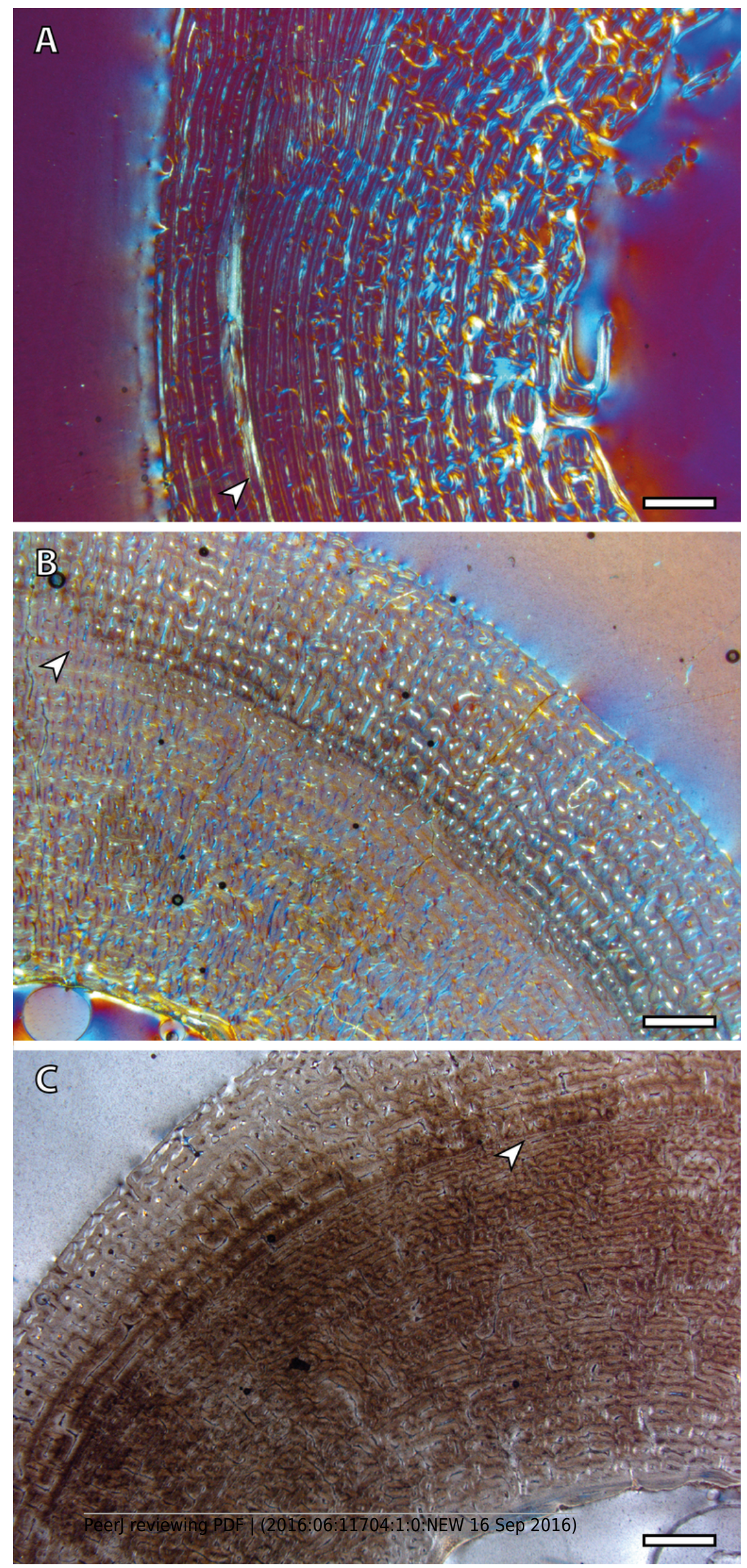


\section{Figure 4}

Bone growth marks in yearling kulans.

A) Femoral bone cortex of IPS83151 showing one BGM in its anterior side. B) Tibial bone cortex of IPS83150 showing two BGMs in its lateral side. C) Metacarpal bone cortex of IPS83151 showing one BGM in its lateral side. D) Metatarsal bone cortex of IPS83149 showing two BGMs in its anterior side. White arrows indicate bone growth marks. Scale bar: 1 millimeter. All images were obtained under polarized light with a $1 / 4 \lambda$ filter. 

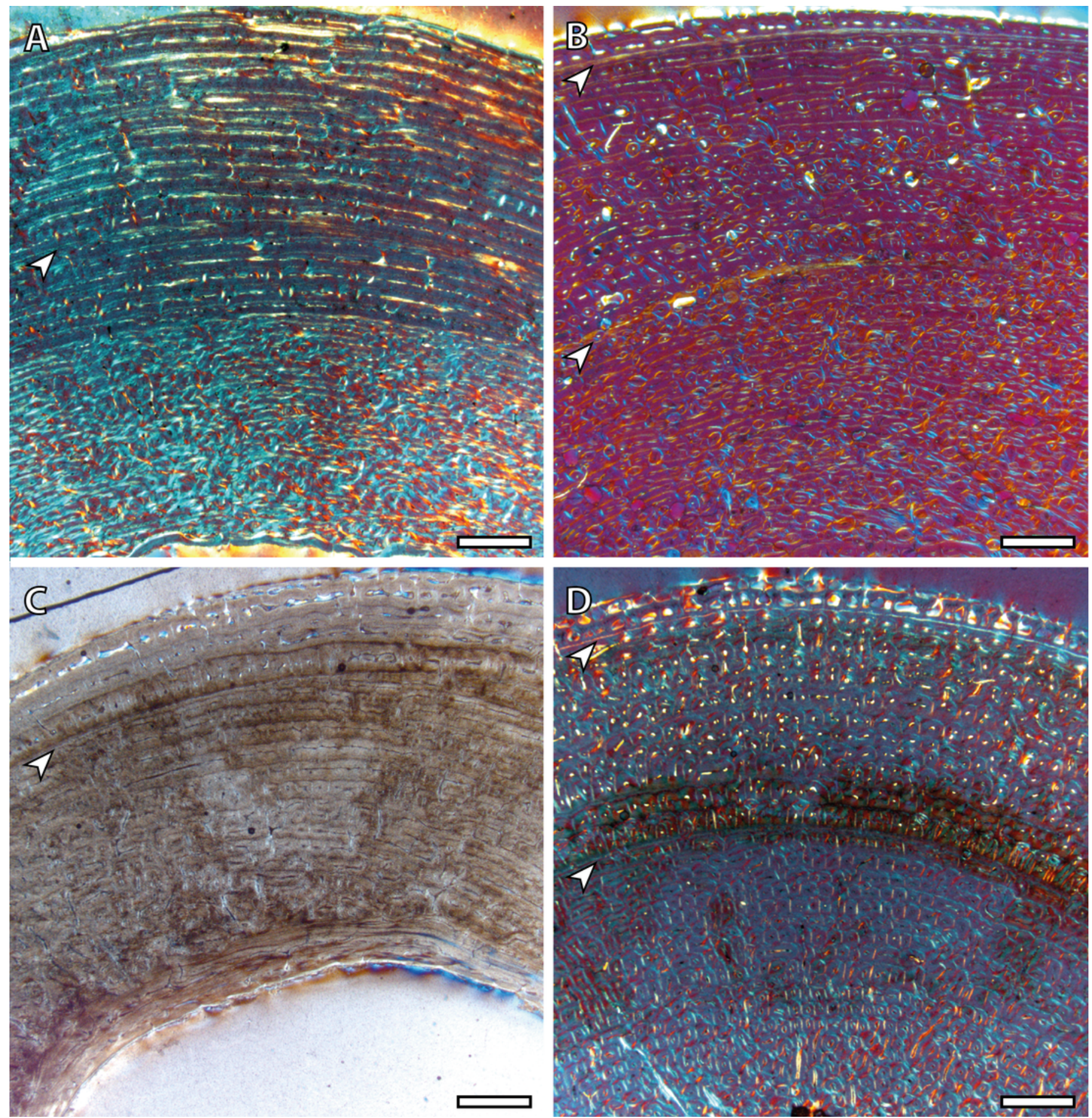


\section{Figure 5}

Bone growth marks in the juvenile kulan (IPS83155).

A) Femoral bone cortex showing one BGM in its anterior side. B) Tibial bone cortex showing two BGMs in its lateral side. C) Metacarpal bone cortex showing one BGM in its anterior side. D) Metatarsal bone cortex showing two BGMs in its anterior side. White arrows indicate bone growth marks. Scale bar: 1 millimeter. All images were obtained under polarized light with a $1 / 4 \lambda$ filter. 

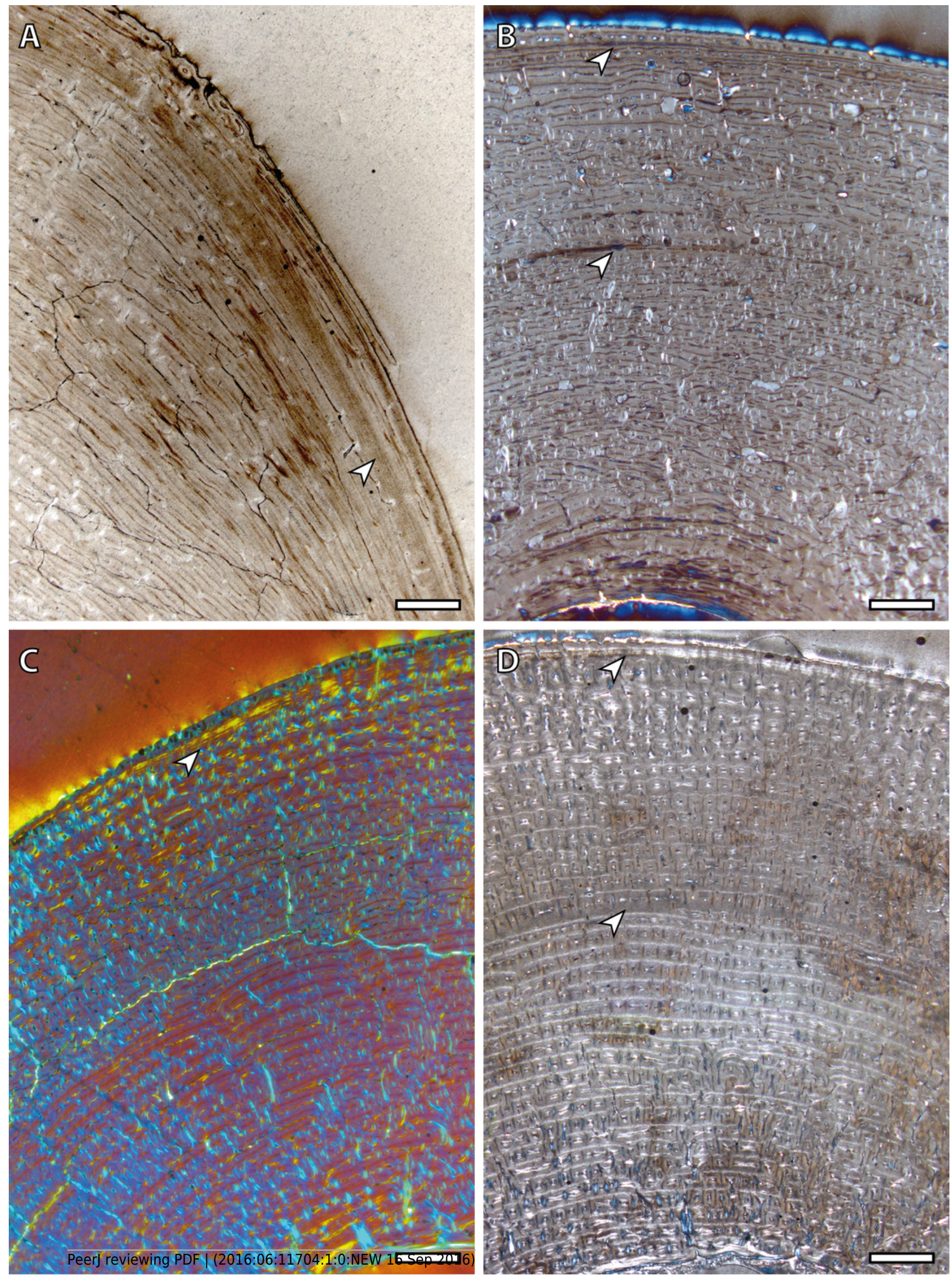


\section{Figure 6}

Bone growth marks in adult kulans.

A) Femoral bone cortex of the wild female (IPS83876) showing five BGMs in its anterior side.

B) Detail of the most external BGMs identified in the femur of IPS83876. Fifth BGM is located within the external fundamental system. C) Tibial bone cortex of the wild male (IPS83877) showing five BGMs in its lateral side. D) Detail of the most external BGMs identified in the tibia of IPS83877. E) Metacarpal bone cortex of the wild female (IPS83876) showing five BGMs in its anterior side. F) Detail of the most external BGMs identified in the metacarpus of IPS83876. Fourth and fifth BGMs are located within the external fundamental system. G) Metatarsal bone cortex of the wild male (IPS83877) showing six BGMs in its anterior side. H) Detail of the most external BGMs identified in the metacarpus of IPS83877. Fifth and sixth BGMs are located within the external fundamental system. White dashed rectangles indicate areas of image magnifications. White arrows indicate bone growth marks. White scale bar: 1 millimeter; black scale bar: 500 microns. All images were obtained under polarized light with a $1 / 4 \lambda$ filter. 

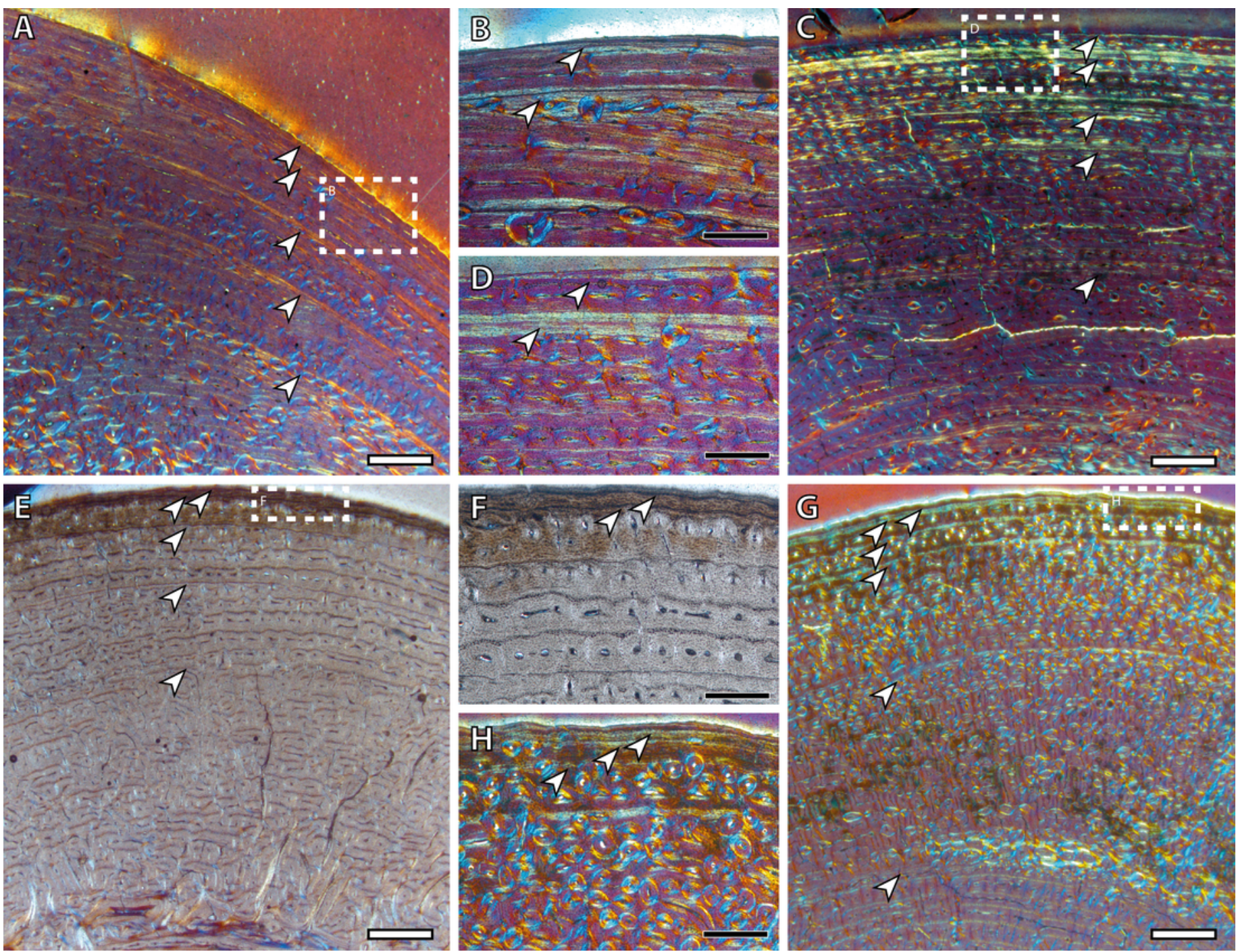


\section{Figure 7}

Bone growth of the Asiatic wild ass.

From $A$ to $D$, bone perimeter ( $\mathrm{mm}$, ordinate axis) is plotted against estimated age (years, abscissa axis) to obtain growth curves. From $E$ to $F$, variation of bone perimeter ( $\mathrm{mm}$, ordinate axis) is plotted against estimated age (years, abscissa axis) as a proxy of growth rate. A) Growth curves obtained from the femora. B) Growth curves obtained from the tibiae. C) Growth curves obtained from the metacarpi. D) Growth curves obtained from the metatarsi. E) Femoral growth rate. F) Tibial growth rate. G) Metacarpal growth rate. H) Metatarsal growth rate. Legend is shown in the bottom of the figure. In the graphs, filled characters represent females, unfilled ones correspond to males and linear ones indicate animals with unknown sex. Dashed lines indicate wild animals while continuous lines represent captive ones. Male and female symbols indicate the time of deposition of the external fundamental system (EFS) in each wild adult respectively. It could be noted that this moment does not match with the decline in periosteal growth rate. 
A

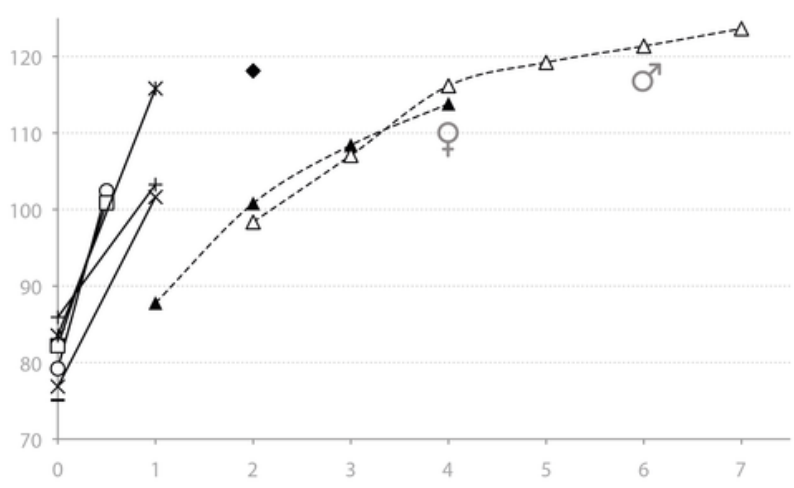

B

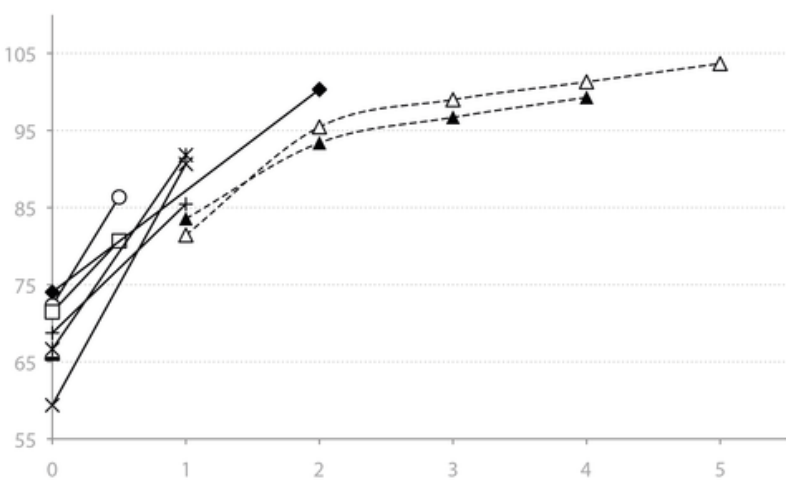

C

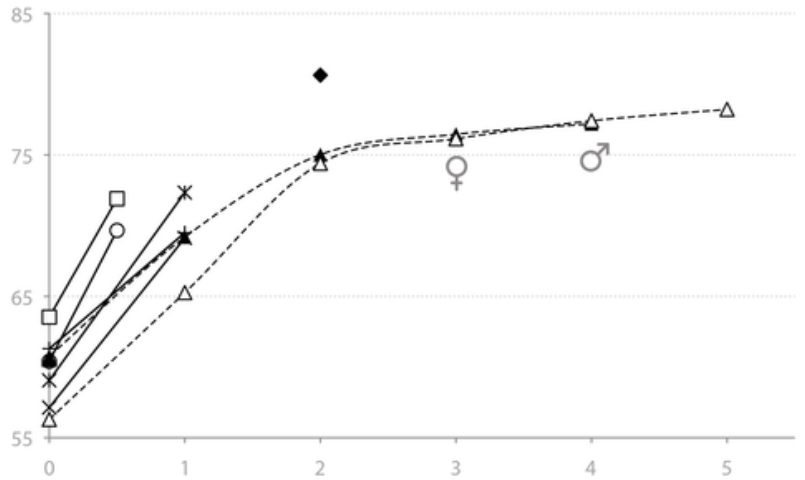

D

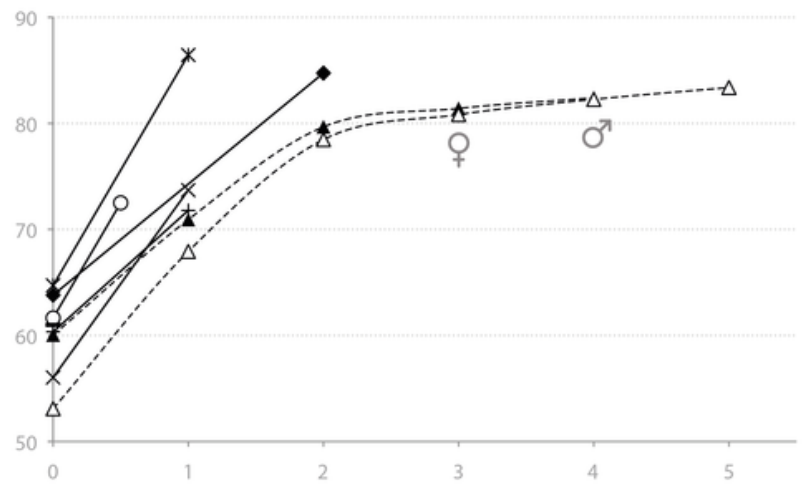

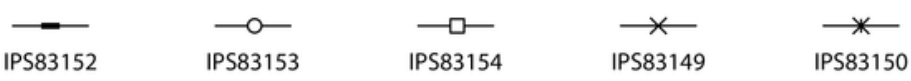

E

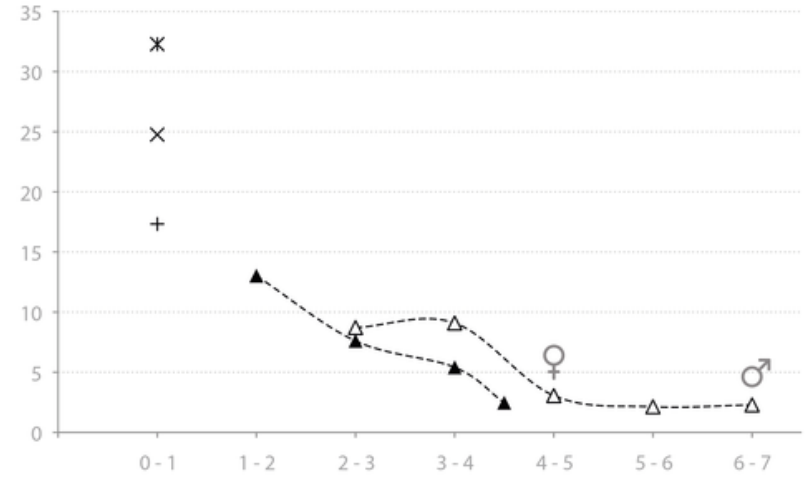

$\mathbf{F}$

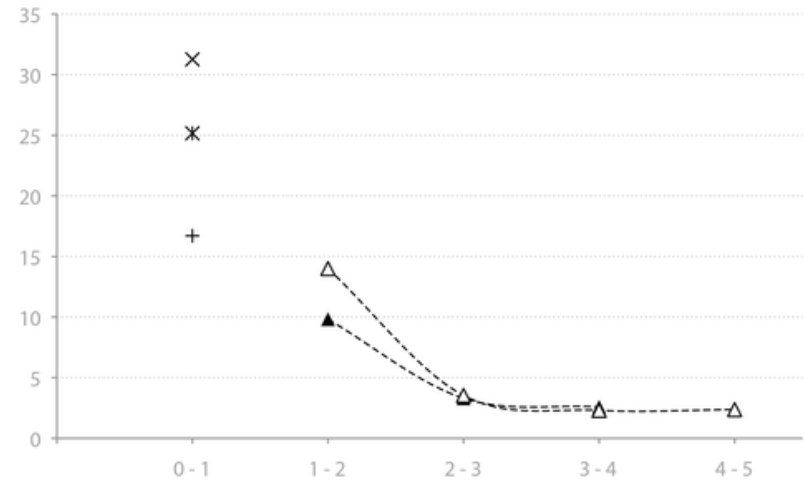

G

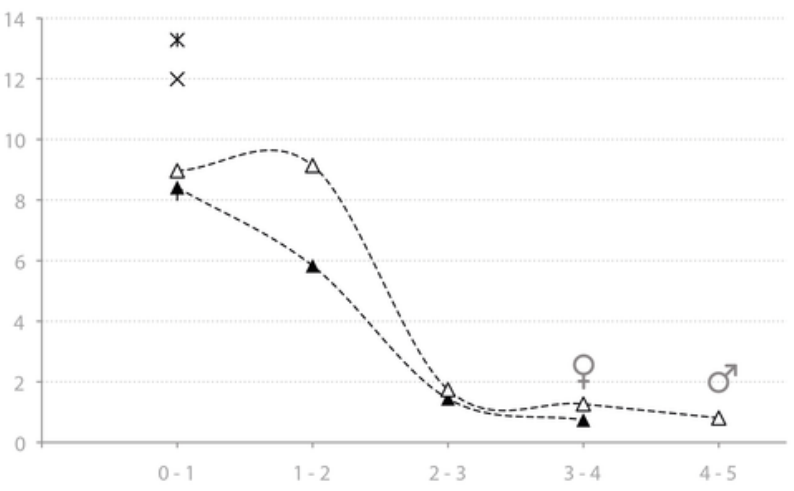

H
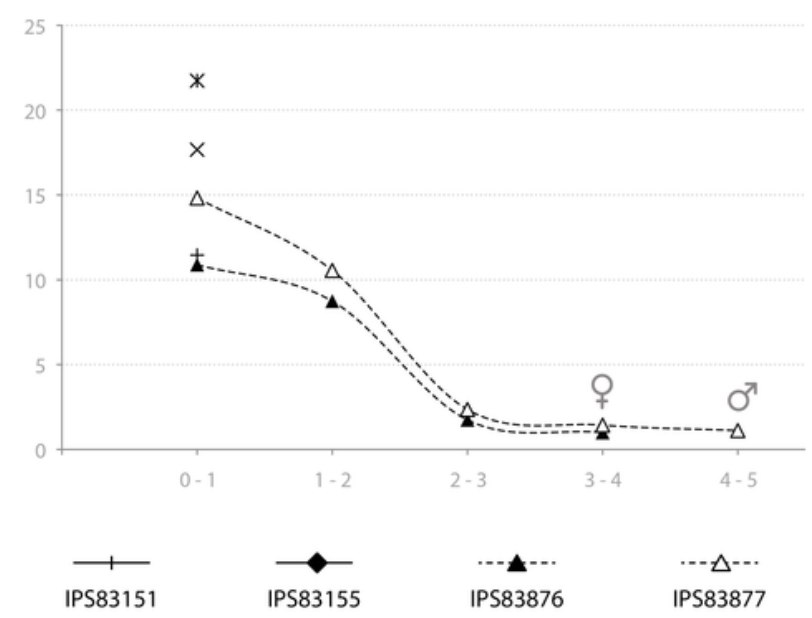